\title{
Pengambilan Keputusan Seorang Istri Dalam Pernikahan Poligami
}

\author{
Sri W. Rahmawati \\ Fakultas Psikologi \\ Universitas Tama Jagakarsa \\ Jl. Letjen TB Simatupang No. 157, Jakarta Selatan \\ swrahma@yahoo.com
}

\begin{abstract}
Polygamy marriage is a social reality that occurs in our community, which responded with a variety of responses. Dynamics of wedding process is something unique. This paper is a qualitative study of decision making process in women who undergo a polygamous marriage, during the marriage enters the age of 11 years. Decision making is intended to obtain the expected results and avoids conflict. A qualitative design is performed because this approach gives a deeper interpretation of human behavior which quantified difficulty. Decision making is not a simple process, because there are many considerations influenced by subjective factors, such as the preference value, as well as environmental factors.
\end{abstract}

Keywords: polygamy marriage; decision making; qualitative approach.

\begin{abstract}
Abstrak-Pernikahan poligami merupakan realitas sosial yang terdapat pada masyarakat kita, yang ditanggapi dengan berbagai respon. Dinamika perjalanan pernikahan merupakan sesuatu yang unik. Penelitian ini merupakan penelitian kualitatif tentang proses pengambilan keputusan pada wanita yang menjalani pernikahan poligami, pada saat pernikahannya memasuki usia ke 11 tahun. Pengambilan keputusan yang dilakukan dimaksudkan untuk memperoleh hasil yang diharapkan dan terhindar dari konflik. Pendekatan kualitatif dilakukan karena pendekatan ini memberikan penghayatan yang lebih mendalam terhadap perilaku manusia yang sulit dikuantifikasikan. Pengambilan keputusan yang diambil bukanlah merupakan proses sederhana, karena di dalamnya terdapat banyak pertimbangan yang dipengaruhi pula oleh faktor subjektif seperti preferensi nilai, maupun faktor lingkungan.
\end{abstract}

Kata kunci: Pernikanan poligami; pengambilan keputusan; pendekatan kualitatif.

\section{PENDAHULUAN}

Pernikahan merupakan perjalanan penting dalam kehidupan seseorang, dan merupakan salah satu tugas perkembangan usia dewasa awal (Hurlock, 2001). Bagi mereka yang sudah menikah, perjalanan untuk 
mempertahankan keutuhan rumah tangga bukan merupakan sesuatu yang mudah. Tak jarang, salah paham mewarnai perjalanan tersebut; hingga permasalahan rumah tangga lainnya, seperti adanya pihak ketiga yang masuk dalam proses berumah tangga dan menjadi bagian dari keluarga. Kondisi demikian akan mendorong pasangan suami istri berada pada situasi konflik. Kondisi konflik tersebut akan berpengaruh pada keutuhan rumah tangga bila dibiarkan berlarut-larut. Pengaruh dari konflik tersebut tidak sederhana, salah satunya akan berdampak pada anak-anak yang merupakan buah hati dalam keluarga (Hughoghi, 2004 dalam Hughoghi dan Long, 2004). Agar konflik tidak berkepanjangan, maka pasangan suami istri dituntut untuk melakukan pengambilan keputusan.

Saat menghadapi konflik rumah tangga, pengambilan keputusan perlu dilakukan dengan maksud untuk memperoleh hasil yang diharapkan dan terhindar dari situasi yang bertentangan (Atwater, 1994). Salah satu persoalan rumah tangga yang sering berkembang menjadi konflik adalah pilihan pasangan hidup untuk melakukan pernikahan poligami. Sebagian masyarakat menganggap poligami berpengaruh pada kepercayaan diri seseorang, hingga pada degradasi diri (Gordon, 1996). Namun demikian, ada sebagian orang yang memilih untuk menyelesaikan konflik rumah tangga dengan menerima poligami sebagai proses perjalanan pernikahannya. Sebuah penelitian yang dipublikasikan oleh Guttmacher Institute dengan judul Women's decision making pre and post marriage pada tahun 2011 (Anynomus,2011), menyatakan bahwa terjadi perbedaan proses pengambilan keputusan antara wanita yang sudah menjalani biduk rumah tangga, bila dibandingkan dengan wanita yang belum menikah.

Penelitian ini bertujuan untuk menggali proses pengambilan keputusan yang terjadi pada wanita yang telah menjalani pernikahannya selama 11 tahun. Pada subjek penelitian ini, pengambilan keputusan dilakukan wanita tersebut sebagai salah satu alternatif upaya untuk keluar dari konflik rumah tangga. Implikasi dari pengambilan keputusan yang diambil oleh wanita ini membuatnya beradaptasi dengan kondisi pernikahannya.

\section{Pengambilan Keputusan}

Beberapa ahli memberikan batasan mengenai pengertian pengambilan keputusan. Morgan (2001) menyatakan pengambilan keputusan sebagai suatu bentuk pemecahan masalah di mana seseorang dihadapkan pada sejumlah pilihan alternatif yang harus diambil. Sementara menurut Baron \& Byrne (1996), pengambilan keputusan merupakan suatu proses yang perlu dilalui oleh seseorang atau sekelompok orang dengan mengkombinasikan dan mengintegrasikan informasi yang berkaitan, sehingga dapat dipilih satu alternatif tindakan tertentu dari beberapa kemungkinan yang ditawarkan. Harris (2012) menyatakan:

"Decision making is the study of identifying and choosing alternatives based on the values and preferences of the decision maker. Making a decision implies that there are alternative choices to be considered, and in such a case we want not only to identify as many of these alternatives as possible but to choose the one that best fits with our goals, desires, lifestyles, values and so on" (Harris, 2012). "Pengambilan keputusan merupakan sebuah studi untuk melakukan identifikasi serta memiliki alternatif yang berlandaskan pada nilai dan pilihan-pilihan yang dimiliki seseorang. Melakukan suatu pengambilan keputusan berarti melibatkan pertimbangan beberapa alternatif. Pada kondisi kasus tertentu, kita tidak hanya mengidentifikasikan banyaknya alternatif yang tersedia, namun juga memilih alternatif yang paling sesuai dengan tujuan kita, keinginan, gaya hidup, nilai dan hal-hal lain" (Harris, 2012)

Secara ringkas dapat disimpulkan bahwa pengambilan keputusan berkaitan dengan cara pemecahan masalah yang dilakukan seseorang saat dihadapkan pada sejumlah alternatif pilihan. Seseorang akan 
mempertimbangkan alternatif yang dipilih sesuai dengan tujuan yang ia miliki, nilai, gaya hidup, maupun keinginannya.

Pada umumnya terdapat tiga tipe keputusan (Harris, 2012), yakni: (a) keputusan bila (decision wheter), yaitu keputusan yang dibuat sebelum seseorang mengambil tindakan, (b) keputusan yang mana (decision which), pada tipe ini seseorang memilih satu alternatif di antara serangkaian alternatif yang tersedia dengan mempertimbangkan kriteria yang diinginkan, dan (c) keputusan yang terkait dengan hal lain (contingent decision), yaitu keputusan yang dalam pengambilannya akan mempertimbangkan hal lain, di mana keputusan tersebut dapat ditunda pelaksanaannya hingga tercapai kondisi tertentu yang dirasakan tepat. Willen dan Wolhan, 1995 (dalam Ranyard, Crozier \& Svenson, 1997) menambahkan ada satu tipe keputusan lain, yaitu personal decision making, keputusan penting yang dibuat seseorang dalam kehidupan pribadinya.

\section{Proses Pengambilan Keputusan}

Menurut Kozielecki (1975), secara umum terdapat dua teori yang dapat menjelaskan tentang proses pengambilan keputusan, yaitu: Pertama, teori pengambilan keputusan prescriptive/normative. Fokus teori ini adalah menemukan metode/cara yang efektif agar diperoleh solusi yang tepat dan menjelaskan bagaimana keputusan secara rasional dibuat. Kedua, teori pengambilan keputusan deskriptif (descriptive). Teori ini menjelaskan tentang dalil-dalil umum yang dapat menggambarkan perilaku aktual dari dilakukan pengambil keputusan.

Proses pengambilan keputusan dapat dijelaskan melalui tahapan-tahapan sebagai berikut (Janis \& Mann, 1977):

Tahap pertama, menerima tantangan untuk berubah. Pada saat seseorang merasa tidak nyaman dalam kondisi tertentu, pada saat itulah ia merasakan bahwa ada kesempatan dan tantangan untuk berubah. Pemahaman yang tepat akan tantangan perlu dimiliki agar pengambil keputusan terhindar dari asumsi-asumsi yang salah atau sikap terlalu memandang remeh masalah. Pertanyaan kunci dalam tahapan ini adalah: Apa yang akan timbul bila saya tidak melakukan sesuatu atau tidak berubah dari kondisi saya sekarang? Apa risiko yang timbul bila saya melakukan sesuatu atau berubah dari kondisi saya sekarang?

Tahap kedua, menilai alternatif. Setelah seseorang merasa yakin akan keinginannya untuk berubah, ia mulai memfokuskan perhatiannya pada satu atau beberapa alternatif. Hal yang terpenting dari tahapan ini adalah keterbukaan dan fleksibilitas dari pengambil keputusan untuk mengumpulkan semua informasi tentang alternatif yang mungkin.Pertanyaan kunci tahap ini adalah: Sudahkah saya menilai semua alternatif?

Tahap ketiga, menimbang alternatif. Seseorang akan mulai memilih alternatif yang terbaik di antara berbagai pilihan yang tersedia, dengan mempertimbangkan keuntungan, kerugian dan kepraktisan dari tiaptiap alternatif hingga ia merasa cukup yakin untuk memilih satu alternatif yang paling tepat. Pada tahap ini bisa jadi ia merasa tidak puas, mengalami tekanan (stress) hingga membuatnya harus mundur dulu ke tahap dua. Pertanyaan kunci pada tahap ini adalah: manakah alternatif yang terbaik? Bisakah alternatif yang dipilih memenuhi persyaratan yang diinginkan?

Tahap keempat, membuat komitmen. Pengambil keputusan akan mulai mengambil suatu rencana tindakan tertentu dan cara mengimplementasikannya atau menyampaikan keinginannya tersebut pada orang lain. Ia pun akan mempersiapkan argumen-argumen yang mendukung pilihannya tersebut, khususnya bila ia berhadapan dengan orang-orang yang menentang keputusan yang diambil. Pertanyaan kunci tahap ini adalah: 
Kapan saya akan mengimplementasikan alternatif yang telah saya pilih? Kapan saya siap memberitahukan orang lain mengenai keputusan yang saya pilih?

Tahap kelima, menghadapi umpan balik negatif. Keputusan yang telah diambil biasanya akan mendapatkan reaksi berupa umpan balik yang negatif. Hal ini bisa mempengaruhi pengambil keputusan karena ia menghadapi tantangan atau ancaman baru. Pada tahap ini penting bagi seseorang untuk tidak bersikap berlebihan terhadap umpan balik negatif dan buru-buru berubah pikiran. Pertanyaan kunci pada tahap ini adalah: Apakah ada resiko serius bila saya berubah? Apakah ada resiko yang lebih serius lagi bila saya tidak berubah?

Proses pengambilan keputusan biasanya merupakan proses yang non liner (atau recursive). Artinya proses pengambilan keputusan tidak selamanya melalui aliran yang konstan. Kebanyakan keputusan dibuat setelah melalui pertimbangan berulang-ulang.

\section{Pertimbangan dalam Proses Pengambilan Keputusan}

Pertimbangan-pertimbangan dalam proses pengambilan keputusan dapat dibagi dalam dua kelompok: Pertama, pertimbangan-pertimbangan utilitarian (kebermanfaatan suatu keputusan). Pertimbangan ini berhubungan dengan manfaat dari suatu yang dibuat keputusan. Pertimbangan ini menyangkut dua hal, yaitu: pertimbangan keuntungan dan kerugian bagi diri sendiri, di dalamnya mencakup antisipasi pengaruh keputusan terhadap kesejahteraan pribadi pengambil keputusan; dan pertimbangan keuntungan dan kerugian bagi orang lain termasuk hal-hal yang sudah diantisipasi akan berpengaruh pada individu yang memiliki pengaruh penting dalam kehidupan seseorang. Kedua, pertimbangan-pertimbangan non-utilitarian (atau pertimbangan bukan dari sisi manfaat/kegunaan). Merupakan pertimbangan lain yang bukan termasuk kegunaan dari suatu keputusan. Pertimbangan ini terdiri dari dua hal pula, penerimaan dan penolakan diri sendiri, termasuk di dalamnya emosi/perasaan dan harga diri seseorang; dan penerimaan dan penolakan dari orang lain, termasuk di dalamnya kritik/penghargaan yang akan diberikan orang lain sehubungan dengan alternatif yang dipilih (Ranyard, Crozier \& Svenson, 1997).

Selain pertimbangan-pertimbangan tersebut di atas, maka terdapat pula faktor-faktor yang mempengaruhi proses pengambilan keputusan, yaitu: Pertama, lingkungan luar. Pada pengambilan keputusan yang bersifat pribadi, proses pengambilan keputusan tidak hanya menuntut kerja aspek kognitif semata, namun berkaitan pula dengan lingkungan. Suatu keputusan berkaitan erat dengan konteks saat keputusan itu dibuat (Kemdal \& Montgomery, dalam Stevenson, 1993). Kedua, pentingnya keputusan yang dibuat. Ada keputusan yang membutuhkan pemikiran yang mendalam, namun ada pula yang dianggap kurang penting. Pertimbangan mengapa suatu keputusan dianggap penting, biasanya berkaitan pula dengan masalah biaya dan konsekuensi dari keputusan tersebut. Selain itu berkaitan pula dengan opini tertentu atau nilai-nilai emosional dari pengambilan keputusan. Penting tidaknya suatu keputusan berpengaruh pada keterlibatan dari pengambil keputusan, yaitu motivasi serta usaha kognitif(berupa strategi yang digunakan) seseorang dalam memecahkan masalah (Stevenson, 1993). Ketiga, tekanan-tekanan berupa keterbatasan waktu, tanggung jawab yang berlebihan, informasi yang minim atau sebaliknya terlalu banyak serta adanya ancaman sosial atau ancaman fisik, dapat menimbulkan stres dan mempengaruhi kualitas keputusan yang dibuat. Keempat, preferensi dan nilai-nilai. Alternatif atau tindakan yang akan dilakukan seseorang sangat bergantung pada preferensi dan nilai-nilai yang dianut oleh seseorang (Harris, 2012). Kelima, waktu dan sumber daya yang dimiliki akan mempengaruhi proses pengumpulan informasi dan penelusuran akan alternatif-alternatif yang dibuat. 


\section{METODE}

\section{Partisipan}

Partisipan dalam penelitian ini adalah seorang perempuan yang sudah berkeluarga. Pengambilan kasus tunggal tersebut didasari perlunya pengungkapan informasi secara mendalam sehingga tergambat proses pengambilan keputusan yang terjadi. Hal ini sesuai dengan prinsip yang dikemukakan Banister, 1994 (dalam Poerwandari, 2011) yang menyebutkan kasus tinggal dapat digunakan bila secara potensial dapat menggambarkan fenomena yang terjadi.

Identitas partisipan terlampir dalam tabel di bawah ini:

Tabel 1. Identitas Partisipan.

\begin{tabular}{ll}
\hline \multicolumn{1}{c}{ Nama } & \multicolumn{1}{c}{ AK (perempuan, 38 tahun) } \\
\hline Pekerjaan & Ibu rumah tangga \\
Pendidikan & S1 - tidak selesai \\
Nama Suami & RP (usia 38 tahun) \\
Pekerjaan & Swasta, bidang pengadaan komputer dan layanan purna jual \\
Pendidikan & D3 \\
Usia pernikahan saat ini & 17 tahun \\
Jumlah anak & 5 orang (3 perempuan/2 laki-laki) \\
\hline
\end{tabular}

\section{Desain}

Pernikahan poligami merupakan fenomena sosial yang bersifat unik dan belum banyak terungkap, salah satunya dikarenakan stigma negatif masyarakat terhadap pernikahan poligami tersebut (Davidson \& Moore, 1996). Pengambilan keputusan yang dilakukan oleh partisipan dalam penelitian ini memiliki sifat yang sangat subjektif dan tidak bebas nilai, dan dipengaruhi pula oleh penghayatan dalam memandang lembaga pernikahan. Dikarenakan kekhususan karakteristiknya, diperlukan kedalaman proses untuk mengungkap fenemona tersebut, sehingga memungkinkan terjadinya proses penyelidikan secara mendalam (Sarantakos, 1993 dalam Poerwandari, 2011). Berdasarkan pertimbangan tersebut, maka riset ini menggunakan metode kualitatif tipe studi kasus.

\section{Prosedur}

Pengumpulan data dilakukan melalui metode wawancara berstruktur dan observasi. Wawancara dilakukan langsung pada subjek, sebanyak 3 kali di kediaman partisipan. Secara umum wawancara berlangsung lancar, responden terlihat sudah dapat menerima kondisi pernikahannya. Hingga saat ini ia sudah menjalani pernikahan poligami selama 5 tahun. Hasil wawancara direkam dalam tape recorder, dilengkapi dengan catatan secara tertulis. Selain teknik wawancara, pengambilan data juga dilengkapi dengan teknik observasi, dengan tujuan mendeskripsikan situasi yang dipelajari, aktivitas yang sedang berlangsung, orangorang yang terlibat dalam aktivitas tersebut, serta makna kejadian dilihat dari sudut pandang partisipan (Patton, 1990 dalam Poerwandari, 2011). 


\section{Teknik Analisis}

Berdasarkan hasil wawancara dan observasi, peneliti melakukan analisis terhadap data yang diperoleh mengacu pada konsep yang digunakan peneliti sesuai literatur dan disiplin ilmu terkait. Jawaban dari partisipan diolah dengan mengacu pada teknik analisis data yang dikemukakan Patton (1990, dalam Poerwandari, 2011). Langkah tersebut yakni: (a) mereprentasikan secara kronologis peristiwa yang diamati, (b) merepresentasikan insiden-insiden kritis atau peristiwa kunci berdasarkan urutan kepentingan insiden tersebut, (c) mendeskripsikan setiap tempat atau lokasi sebelum merepresentasikan gambaran dan pola umumnya, (d) memfokuskan analisis pada individu/kelompok yang menjadi unit analisis primer, (e) mengorganisir data dengan menjelaskan proses yagn terjadi, serta (f) memfokuskan pengamatan pada isu-isu kunci yang diperkirakan sejalan dengan upaya menjawab pertanyaan primer penelitian. Hasil analisis kemudian disajikan dalam bentuk deskripsi sesuai dengan teori yang dijadikan acuan, sehingga lebih sistematis

\section{ANALISIS \& HASIL}

\section{Profil Subjek Penelitian}

AK menikah pada tahun 1998, dengan proses yang difasilitasi oleh guru pembina pengajian dan disetujui oleh kedua keluarga besar. AK adalah seorang aktivis agama yang sudah terlibat pengajian sejak usia SMA. Salah satu peserta pengajian adalah RP yang saat itu merupakan bakal suaminya, menimba ilmu di tempat yang sama. Sejak dulu AK mengenal RP sebagai laki-laki yang populer dan banyak disukai oleh kaum wanita, terutama oleh teman-teman AK sendiri. Proses perkenalan dengan suaminya berlangsung cukup lama, karena keterlibatan mereka dalam aktivitas pengajian. Namun proses serius untuk menindaklanjuti hubungan tersebut ke jenjang pernikahan berlangsung pada tiga bulan terakhir menjelang pernikahan.

Keluarga besar keduanya mendukung penuh pernikahan yang dilakukan dan relatif tidak ada permasalahan yang timbul. Satu persatu anak mereka lahir dan sejak menikah AK serta suaminya, RP, tinggal di rumah orang tua AK. Rumah yang cukup luas tersebut kemudian dibuatkan bangunan tersendiri untuk AK dan anak-anaknya.

RP dikenal sebagai laki-laki tampan dengan wajah yang awet muda (baby face). Pembawaannya juga tenang, namun senang bergurau. Ia tipikal orang yang tidak pernah menanggapi persoalan secara serius (cenderung easy going). Hal ini berbeda dengan karakter AK yang dikenal serius, sungguh-sungguh, berpikir panjang, tanggung jawab sebelum menghadapi persoalan dan sering memiliki banyak pertimbangan. Selama pernikahan berlangsung, relatif tidak ada masalah dalam hubungan suami istri yang terjadi. Selain mengelola rumah tangga AK pun sibuk dengan aktivitas mengelola pengajian yang cukup menguras waktu.

Hubungan AK dengan keluarga besar suaminya berlangsung baik, demikian pula sebaliknya. Keluarga yang masih tinggal dalam satu kota menjaga relasinya dengan banyak berkunjung.

Sepanjang pernikahan relatif tidak banyak masalah yang terjadi bila dikaitkan dengan perlakuan RP terhadap keluarga dan diri AK sendiri. Pada tahun 2000, pada saat pernikahan mereka berusia 12 tahun, AK menangkap gelagat di mana suaminya secara rutin tidak pulang ke rumah 1-2 hari dalam satu bulan. Biasanya RP beralasan untuk masalah pekerjaan. AK mempercayai alasan suaminya dan tidak berpikiran macam-macam. Hingga kemudian seseorang yang merupakan teman kantor RP menelepon ke rumah AK dan memberitahu bahwa suaminya telah menikah lagi dengan perempuan lain. 
Terkejut dengan kabar tersebut, AK segera bertindak. Pada saat RP pulang kerja, AK menanyakan apakah benar RP telah menikah lagi. Pada awalnya RP menjawab dengan berbelit-belit, namun ketika AK menyajikan beberapa data seperti: sering tidak pulang ke rumah, ditemukan kuitansi biaya atas nama orang lain hingga informasi yang diberikan oleh teman kantornya, RP tidak dapat mengelak dan mengakui bahwa ia telah menikah dengan seorang gadis berusia 18 tahun yang pada saat itu sedang magang bekerja di kantornya. RP beralasan perlu menikahi gadis tersebut karena merasa tidak enak dengan fitnah yang ada di kantor tentang kedekatannya dengan gadis itu. Selain itu RP juga tidak ingin terjerumus pada perbuatan zina, di mana ia dan gadis tersebut sudah sama-sama suka. Pada saat pernikahan berlangsung, RP dan AK telah memiliki anak empat orang dan usia anak tertua adalah 10 tahun dan anak yang paling kecil 5 tahun.

Setelah memiliki cukup kekuatan, AK membawa masalah ini kepada keluarga besarnya (ibu, bapak dan saudara kandung AK) untuk menceritakan permasalahan. Semua reaksi keluarga menyatakan kaget dan tidak dapat menerima bila AK 'dimadu' (suami memiliki istri lain di samping dirinya). Seluruh keluarga memberikan reaksi agar AK memutuskan saja pernikahan yang sudah dijalani dan keluarga sudah siap untuk berbicara dengan besannya. Pada saat itu AK merasa benar-benar bingung, di satu sisi ia tidak memiliki keterampilan khusus yang akan mendukung dirinya untuk mencari nafkah bagi anak-anaknya, sementara di sisi lain keluarga memberikan saran untuk bercerai saja. AK belum memberi tahu pada anak-anaknya karena pertimbangan usia anak yang masih kecil-kecil dan dianggap belum mengerti permasalahan ini, di samping AK pun cemas dengan dampak negatif yang mungkin akan timbul.

Selama proses tersebut berlangsung, RP tetap menjalankan perannya sebagai suami. Ia juga tetap dekat dengan anak-anak dan memberikan nafkah bulanan secara rutin. RP berusaha meyakinkan AK bahwa keputusan yang diambil tidak akan mengurangi rasa cintanya pada AK dan anak-anaknya, dan pernikahan yang sudah dilakukan dengan istri mudanya, anggaplah sebagai upaya untuk menghindari diri dari perzinaan.

Berkali-kali AK sakit dan harus istirahat penuh di rumah. Sebenarnya ia sendiri memiliki riwayat kesehatan yang tidak terlalu baik. Sejak kelahiran anak yang kedua, ia menderita kista dalam rahim yang menyebabkan dirinya harus melakukan operasi pengangkatan kista. Aspek ini mempengaruhi pula kualitas hubungan suami-istri yang mereka lakukan, dan seringnya AK kambuh dengan penyakitnya beberapa kali dalam satu bulan.

AK mencari saran pada beberapa teman dekat dan keluarga besarnya, mengenai tindakan yang harus diambil. Dalam proses tersebut RP menyerahkan keputusan akhir pada AK. Ia siap untuk bercerai. Namun bila rumah tangga tetap berlangunsg, ia juga berjanji akan tetap bertanggung jawab dan memberikan nafkah serta perhatian yang memadai untuk anak-anaknya.

Hal lain yang mengagetkan bagi AK, ternyata RP telah membicarakan proses pernikahan yang kedua ini dengan keluarga besarnya (ayah dan ibu mertua AK). Keduanya bahkan menjadi saksi dalam pernikahan tersebut. Atas tindakan ini, keluarga besar AK merasa tersinggung, namun akhirnya menyerahkan keputusan sepenuhnya pada AK.

Setelah melalui proses pertimbangan panjang, AK memutuskan untuk mempertahankan pernikahannya, merelakan suaminya berbagi dengan perempuan lain. AK kemudian hamil anak yang kelima dan pada saat ini usia anak tersebut adalah 6 tahun. Dari pihak madunya, ia juga memiliki anak dengan usia yang sama (6 tahun). AK sering kontak dengan madunya bahkan sekarang anak madunya tersebut sering menginap di rumah $\mathrm{AK}$. 


\section{Analisis Data Penelitian}

Pengambilan keputusan yang dilakukan AK tergolong pada personal decision making, keputusan yang relatif penting yang dibuat seseorang dalam kehidupan pribadinya (Willen danWolhan dalam Ranyard, 1997): "sangat berat menerima kenyataan bahwa suami memiliki istri muda, namun meskipun keluarga besar saya mendukung apa pun yang akan saya lakukan, saya perlu berhati-hati mengambil keputusan ini karena ini menyangkut masa depan saya dan anak-anak"

\section{Proses Pengambilan Keputusan}

Pengambilan keputusan yang dilakukan AK akan digambarkan melalui teori descriptive yang berusaha menjelaskan proses pengambilan keputusan secara aktual oleh seorang istri untuk tetap mempertahankan pernikahannya.

Analisis terhadap proses pengambilan keputusan yang dilakukan AK digambarkan melalui teori Janis \& Mann (1977), dengan pertimbangan, bahwa teori ini mendukung pendekatan deskriptif yang digunakan dalam penelitian. Pendekatan ini tidak bermaksud untuk menentukan rasional/tidaknya suatu proses pengambilan keputusan, namun lebih menekankan pada pemahaman dinamika proses pengambilan keputusan. Selain itu Janis \& Mann (1977) telah memformulasikan pertanyaan-pertanyaan kunci yang dapat diajukan untuk menggali proses pengambilan keputusan.

Tahap-tahap dalam proses pengambilan keputusan AK berlangsung sebagai berikut:

1. Tahap 1: Menerima tantangan untuk berubah.

Setelah AK mengetahui informasi bahwa RP menikah lagi, maka AK dihadapkan pada kenyataan baru yang melibatkan kondisi emosi dan perasaannya. Kondisi ini diikuti dengan tantangan baru, apakah akan tetap mempertahankan rumah tangganya dengan menerima kehadiran madunya, atau akan berpisah dengan suaminya:

"... sedih banget saat tahu kalau suami menikah lagi. Padahal selama ini komunikasi di antara kami berlangsung baik. Saya selalu terbuka menceritakan semua kegiatan saya, saya rasa ia pun demikian. Tapi kenapa untuk masalah yang penting ini -pernikahan- dia gak bicarakan dulu dengan saya. Tahu-tahu saya tahu setelah pernikahan mereka jalan 3 bulan..."

"... waktu saya tanya, kenapa gak ngomong dulu..., suami malah bilang, sebenarnya saya bukannya gak ingin jujur tapi saya perlu menunggu saat yang tepat untuk memberitahu kamu.."

"... pernikahan ini membawa masalah baru buat saya, apakah saya akan tetap bertahan dengan pernikahan ini atau memutuskan saja untuk bercerai. Saya $u d a h$ punya empat anak, semua perubahan yang terjadi akan berdampak besar pada anak-anak saya...”

\section{Tahap 2: Menilai alternatif.}

Setelah seseorang merasa yakin akan keinginannya untuk berubah, ia mulai memfokuskan perhatiannya pada satu atau beberapa alternatif.

"...keluarga saya sih udah nyerahin keputusan ini sama saya. Kalau emang mau cerai, mereka udah siap datang ke besan untuk bicara. Tapi kalau mau tetap bertahan, ya.. mereka juga akan hargai keputusan saya..."

"... saya coba bicara dengan orang-orang dekat yang saya percaya, bagaimana baiknya. Mereka semua bilang, harusnya dari awal saya bicara kalau gak mau dimadu. Tapi siapa yang tahu kalau suami kita punya niat kayak gitu...?" 
"... apa mungkin suami saya menikah karena saya punya penyakit kista ya.. dia gak pernah ngomong-ngomong ini ke saya. Hubungan suami istri tetap berjalan seperti biasa. Mungkin ada hal lain yang dia gak mau sampaikan...."

"... kalau saya cerai, yang jadi kepikiran bagaimana cari nafkah buat anak-anak. Selama ini saya ibu rumah tangga biasa, gak punya kerjaan yang menghasilkan uang, sementara biaya anak-anak pasti gede..."

"... gak kepikiran buat saya kalau harus bertahan hidup dengan madu, apalagi dia masih muda lagi... baru lulus SMA. Rasanya saya jadi punya saingan... Tapi saingan anak lulus SMA ya... kita kalah kalau dari segi fisik...”

\section{Tahap 3: Menimbang alternatif.}

Pada tahap ini seseorang mempertimbangkan semua alternatif yang tersedia, baik dari sisi keuntungan, kerugian maupun kepraktisan setiap alternatif untuk memilih mana yang paling tepat dalam upaya mencapai tujuan tertentu.

"...anak saya yang paling gede kan perempuan, bingung bagaimana ngasih tau kalau bapaknya udah kawin lagi... gimana cara ngasih taunya ke adik-adiknya, pasti dia akan sedih banget..."

"... selama ini kelebihannya emang selalu baik sama anak-anak... biar dia udah menikah lagi, tapi dia tetap sayang dan perhatian... dia juga bilang tetap sayang sama saya dan dia tahu kalau saya masih mencintainya...."

"... guru pengajian saya bilang kalau menikah lagi kan sesuatu yang dibolehkan dalam agama Islam, selama suami mampu berbuat adil... dia juga kasih pertimbangan apa saya tega membiarkan anakanak kehilangan bapaknya, padahal mereka sangat dekat hubungannya dan sedang dalam masa membutuhkan figur ayah..."

\section{Tahap 4: Membuat komitmen.}

Pengambil keputusan mulai mengambil suatu rencana tindakan tertentu dan cara mengimplementasikannya atau menyampaikan keinginannya tersebut pada orang lain. Ia pun akan mempersiapkan argumen-argumen yang mendukung pilihannya tersebut.

"... mungkin ada hikmahnya dari kejadian ini, saya 'kan punya penyakit kista di rahim... itu mempengaruhi banget kesehatan saya. Meski dalam hubungan suami-istri saya tetap melakukannya sebaik mungkin, saya gak tahu apakah suami gak puas... dia pasti gak tega bicarakan itu ke saya, karena dia tahu kalau saya lagi kesakitan (karena penyakit kista) saya bisa terik-teriak..."

"... orang pertama yang perlu saya kasih tau ya... ibu saya sendiri... selama ini 'kan dia yang paling bingung. Namanya juga orang tua, pasti ingin anaknya bahagia... Saya udah memutuskan untuk tetap mempertahankan pernikahan ini..."

"... guru pengajian saya bilang kalau saya ikhlas, jaminannya surga... Lagipula saya juga makin sadar, biar suami sendiri, kita tidak bisa menggantungkan diri sepenuhnya sama dia... Ketergantungan yang paling besar tetap kembali kepada Allah SWT..."

\section{Tahap 5: Menghadapi umpan balik negatif.}

Mempersiapkan diri untuk mendapatkan reaksi berupa umpan balik yang negatif, setelah keputusan diambil. Kondisi ini bisa mempengaruhi seseorang karena ia menghadapi tantangan atau ancaman baru. Penting bagi seseorang untuk tidak bersikap berlebihan terhadap umpan balik negatif dan buru-buru berubah pikiran. 
"... di keluarga saya sebelumnya, gak ada sejarah wanita dimadu dan suaminya berpoligami.. Jadi pasti banyak yang menentang keputusan ini..."

"...gimana lagi, hidup mesti terus berjalan. Anak-anak semakin besar. Kalau saya terus-terusan goyah kayak gini, anak-anak akan jadi korban... mudah-mudahan apa yang saya lakukan akan memberi jalan keluar untuk saya, anak-anak dan keluarga saya. Juga madu saya, gimana juga statusnya dia udah jadi istri suami saya... mau gak mau itu kenyataan yang saya harus hadapi...”

"... buat saya pribadi, hal yang paling berat, justru bagaimana menanggapi respon masyarakat. Udah jamak dalam kebiasaan kita, kalu suami nikah lagi, pasti istri yang akan jadi sorotan. Dianggap tidak pandai melayani, atau terlalu sibuk dengan urusan sendiri... Ya, saya sih siap aja, karena toh pada kenyataannya saya udah berusaha semaksimal mungkin. Kalau suami punya keputusan sendiri, dia pasti juga punya pertimbangan...."

“... usia suami saya sama dengan saya... tapi orang-orang bilang penampilannya masih seperti mahasiswa. Baby face, memang. Ini susahnya punya suami awet muda. Gak jarang orang mengira suami saya itu belum nikah..."

"... suami janji akan tetap pegang komitmen, untuk menafkahi saya dan anak-anak.Ia juga akan berlaku adil, membagi waktu dan perhatian antara keluarga kami dan istri mudanya... Ya, saya mencoba percaya...”

“... lama kelamaan ternyata saya bisa mulai mengurangi rasa sakit hati saya... saya sibukkan diri dengan banyak berdzikir, menyadari ini adalah takdir Allah. Saya juga punya segudang kegiatan pengajian dan kegiatan masyarakat, di samping ngurus anak-anak... Itu membuat saya bisa melupakan masalah ini dan menerima kenyataan baru....”

\section{Faktor yang Mempengaruhi Pengambilan Keputusan}

Faktor-faktor yang berperan dalam proses pengambilan keputusan yang dilakukan AK untuk menerima poligami adalah sebagai berikut:

1. Lingkungan luar.

Saat AK menghadapi masalah pernikahannya, ia memiliki teman cukup dekat yang biasanya dijadikan panutan saat AK mengambil tindakan tertentu. Teman tersebut banyak memberikan nasehat kepada AK agar memilih untuk menerima keputusan suaminya berpoligami. Kebetulan teman dekat ini suaminya pun melakukan poligami meskipun dengan janda yang sudah memiliki dua anak.

“...mbak X bilang kalau saya terima aja keputusan suami... Ya, dia sih enak, suaminya nikah dengan janda yang sudah punya anak... sepertinya masih lebih terhormat.. Beda kan pengalamannya dengan saya. Suami saya nikah dengan remaja lulusan SMA..."

"... setelah dipikir-pikir apa yang dikatakan mbak X benar juga... Usia saya sudah 35 tahun, kalaupun saya bercerai apa yang bisa saya lakukan? Mungkin kalau saya terima takdir ini saya bisa dapat sisi kebaikannya juga..."

2. Pentingnya keputusan yang dibuat

Keputusan yang dilakukan AK merupakan hal yang penting, membutuhkan pemikiran yang mendalam, berkaitan pula dengan masalah konsekuensi dari keputusan tersebut dan nilai-nilai emosional dari 
pengambilan keputusan. Hal ini berpengaruh pada keterlibatan (involvement) AK dalam pengambilan keputusan.

“... masalah pernikahan bukan masalah main-main. Kita mempertaruhkan diri kita sendiri, kelurga besar, anak-anak untuk menjaga masalah ini. Meski rasanya emosi banget, tapi ya saya juga mesti hati-hati memutuskannya..."

3. Tekanan (stres)

Sebagai ibu rumah tangga, AK telah memiliki 4 orang anak (pada saat suaminya berpoligami) dan memiliki tanggung jawab menjadi pembina pengajian. Ia memiliki banyak murid yang mendengar nasehat serta arahannya. Hal ini menimbulkan tekanan tersendiri.

“... sering kalau saya bertemu murid-murid pengajian saya, mereka memandang kasihan.. apa mungkin perasaan saya $a j a \ldots$ ya berat sekali, sih. Mereka juga pasti akan melihat apa yang saya lakukan untuk memecahkan masalah keluarga saya sendiri, karena selama ini saya yang sering bertindak sebagai penasehat buat mereka..."

4. Preferensi dan nilai-nilai

Sebagai seorang yang memiliki ketaatan beragama, AK meyakini bahwa berpoligami sesuatu yang diizinkan dalam aturan agama, sejauh syarat-syarat keadilan dipenuhi.

“... memang dilematis buat saya kalau nyuruh suami menceraikan istri mudanya. Kenyataannya, perempuan itu sudah jadi istrinya, dan pernikahan mereka bahkan disaksikan mertua saya. Ya..., akhirnya saya harus meyakini, poligami memang sesuatu yang dibolehkan dalam agama, apalagi saya juga melihat suami berusaha keras untuk adil, dalam pembagian waktu dan nafkah..."

\section{DISKUSI}

Pernikahan dijalani oleh pasangan yang saling berkomitmen untuk membentuk keluarga. Namun tidak ada satu pun jaminan bila pernikahan yang dilalui akan bebas dari konflik. Konflik tersebut bisa berasal dari perbedaan pandangan mengenai peran dalam keluarga, perbedaan latar belakang antara pasangan, ataupun perkembangan individu yang terlibat dalam ikatan pernikahan tersebut (Argyle, Henderson, dan Furhand, 1985 dalam Davidson \& Moore, 1996). Sejak pertengahan tahun 1970, area-area konflik pada umumnya meliputi masalah komunikasi antar pasangan suami istri, tugas-tugas kerumahtanggaan, karier dan pekerjaan, serta kurangnya waktu personal untuk masing-masing pasangan (Davidson \& Moore, 1996). Saat konflik terjadi, pengambilan keputusan perlu diambil agar konflik dapat segera diredam. Ketika seorang perempuan telah menikah, maka pengambilan keputusan yang dilakukan memiliki perbedaan dengan kondisi ketika ia masih lajang (Yasmin dan Heyna, 2008). Pada beberapa budaya, seperti yang terjadi di budaya Timur, maka pengambilan keputusan bagi perempuan yang telah menikah juga dipengaruhi oleh peran keluarga besar serta nilai-nilai budaya yang tertanam di dalamnya (Kurane, Anjali; Shetty, Jyoti, 2011).

Studi kasus dalam penelitian ini menunjukkan kecenderungan perempuan untuk menyederhanakan konflik yang terjadi dalam pernikahannya, dengan melakukan pengambilan keputusan yang relatif dapat meredam terjadinya konflik baru (Davidson \& Moore, 1996). Sebagai suatu proses yang bersifat individual, maka pengaruh faktor nilai-nilai, keyakinan maupun lingkungan luar memiliki andil yang besar terhadap partisipasi dalam penelitian ini (Harris, 2012). Meskipun konsekuensi dari keputusan yang diambil akan menimbukan dampak tertentu di kemudian hari, namun bagi partisipan konsekuensi tersebut merupakan 
faktor paling ringan yang telah dipertimbangkan dampaknya. Hal ini tidak terlepas pula pada kecenderungan budaya beberapa daerah yang menekankan peran lebih besar bagi laki-laki dalam keluarga. Penelitian Yasmin dan Heyna (2008) menyatakan bahwa peran laki-laki sebagai kepala keluarga yang memiliki otonomi dalam bidang ekonomi, akan jauh lebih memiliki kekuatan untuk membuat keputusan dibandingan peran perempuan dalam keluarga (Yasmin dan Heyna, 2008).

\section{SIMPULAN \& SARAN}

\section{Simpulan}

Pengambilan keputusan merupakan tindakan yang dilakukan saat menghadapi berbagai pilihan. Dalam setting rumah tangga, di mana relasi yang terjadi sifatnya personal, maka pengambilan keputusan dilakukan untuk menghindari terjadinya konflik yang berkepanjangan. Kesimpulan yang dapat diambil dari penelitian ini adalah sebagai berikut:

Pertama, pengambilan keputusan yang dilakukan AK merupakan jenis pengambilan keputusan yang berkaitan dengan masalah sangat pribadi dan ikut memberikan konsekuensi pada pihak-pihak yang terkait (seperti: orang tua, keluarga mertua, anak-anak dan keluarga besar secara umum).

Kedua, proses pengambilan keputusan yang dilakukan sesuai dengan teori pengambilan keputusan dari Janis dan Mann (1977), yang menyatakan bahwa pengambilan keputusan dilakukan melalui 5 tahap. Pertanyaan yang diajukan dalam setiap tahap mencerminkan dinamika yang terjadi, dan bagaimana responden mensikapi permasalahan yang dihadapi.

1. Tahap menilai alternatif (tahap 2) dan menimbang alternatif (tahap 3) sering kali berlangsung secara bolak-balik, karena pada tahap ini proses pengambilan keputusan terjadi paling berat. Pada kasus AK, tahap ini memakan waktu yang relatif paling lama bila dibandingkan dengan tahap-tahap lain.

2. Proses pengambilan keputusan yang dilakukan AK sendiri sangat dipengaruhi oleh lingkungan luar serta preferensi dan nilai yang dimiliki AK. Sebagai seseorang yang taat beragama, AK meyakini bahwa poligami mengandung banyak hikmah, hal tersebut ikut membantu dirinya dalam menentukan keputusan yang diambil. Selain itu beberapa teman AK yang menjalani kehidupan poligami, menjadi faktor luar yang cukup berpengaruh.

\section{Saran}

Saran teoritis maupun saran praktis berdasarkan hasil penelitian ini tercantum di bawah ini:

1. Dinamika pengambilan keputusan pada AK untuk menjalani pernikahan poligami akan lebih lengkap bila diketahui proses yang sama pada RP, suami AK. Pada penelitian lanjutan, hal ini disarankan untuk dilakukan hingga dapat melengkapi data tentang pernikahan poligami, baik dari pasangan istri maupun suami. Dengan demikian dapat diperoleh perbandingan pandangan dari sudut pandang suami mengenai proses yang terjadi ketika memutuskan untuk melakukan poligami.

2. Dalam literatur psikologi Barat, poligami merupakan konsep yang kurang populer. Beberapa jurnal penelitian tentang poligami hampir seluruhnya mengambil latar belakang pada budaya Timur. Khusus di Indonesia, faktor ulayat dari pernikahan poligami ini perlu lebih dipertajam untuk penelitian 
selanjutnya, mengingat latar belakang budaya, nilai, gaya hidup, dan lingkungan eksternal menjadi aspek yang berpengaruh pada proses pengambilan keputusan (Harris, 2012).

3. Bagi pemangku kepentingan, yakni lembaga-lembaga yang mengelola masalah perkawinan, seperti Kantor Catatan Sipil, KUA (Kantor Urusan Agama) dan lembaga penasehat perkawinan, fenomena poligami ini perlu dipertimbangkan sehingga akan memberikan wacana dan masukan bagi peraturan yang dikeluarkan lembaga resmi pernikahan dalam mengelola masalah rumah tangga yang terjadi di di kalangan masyarakat.

4. Untuk konselor perkawinan, termasuk praktisi psikolog, perlu mempelajari secara mendalam fenomena pernikahan poligami, sehingga dapat ditemukan pertimbangan-pertimbangan mendasar yang melandasi pengambilan keputusan yang terjadi. Pemahaman tersebut akan memperkaya praktisi dalam memberikan saran-saran pemecahan masalah bagi persoalan perkawinan yang berlangsung.

\section{DAFTAR PUSTAKA}

Anonymous. (2011). Women's decision making pre and post marriage. International perspectives on sexual and reproductive health. Guttmacher Institute, Proquest Research Library.

Atwater, Eastwood. (1994). Psychology for living: adjustment, growth and behavior today. NJ: Prentice Hall.

Baron R.A, dan Byrne, D. (1996). Social psychology. $8^{\text {th }}$ ed. Massachusettes: Allyn \& Bacon.

Davidson, J Kenneth. \& Moore, Nelwyn B. (1996). Marrage and family. Change and continuity. Massachusetts: Allyn and Bacon.

Gordon, Sarah Barringer. (1996). The liberty of self degradation: poligamy, woman suffrage, and consent in nineteenth-century America. The journal of American history, Proquest Research Library.Houghughi, Masud. \& Long, Nicholas (ed) (2004). Handbook of parenting. theory and research for practice. London: Sage Publication.

Hurlock, Elizabeth B. (2001) Introduction to psychology. A life-span approach. New York: Tata Mc Graw Hill.

Janis, I.L \& Mann, L., (1977) Decision making: A pychological analysis of conflict, choice and commitment. New York: The Free Press.

Kozielecki, Jozef. (1975) Psychological decision theory. Boston: Kluwer Inc.

Kurane, Anjali and Jyoti Shetty. (2010). Women and development: Women in the decision making process in the family. Proquest Research Library.

Morgan, Clifford T., King, R.A., Shinkman, P.G., Waller, P.F., (2001). Introduction to psychology. USA: Mc Graw Hill, Inc.

Poerwandari, E. Kristi., (2011) Pendekatan kualitatif untuk penelitian perilaku manusia. F Psi UI Depok: LPSP3.

Ranyard, Rob., Crozier, WR., \& Svenson, Ola. (1997). Decision making: Cognitive models and explanations. London: Routledge. 
Stevenson, MK. (1993). Decision making with long term consequences: Temporal discounting for simple and multiple outcomes in the future. Journal of Experimental Psychology, General, 122, 3-22.

Yasmin, Hena. (2008). Decision making roles of woman in families. Nurture Journal, December 2008. Proquest Research Library.

\section{Internet}

Harris, Robert. (2012). Introduction to decision making. Diperoleh dari http: //www.virtualsalt.com. diunduh pada tanggal 02 Februari 2013 jam 09.15 wib. 